\title{
Preliminary estimate of spawning frequency and batch fecundity of Brazilian flathead, Percophis brasiliensis, in coastal waters off Buenos Aires Province*
}

\author{
M.I. MILITELLI ${ }^{1}$ and G.J. MACCHI ${ }^{1,2}$ \\ ${ }^{1}$ Instituto Nacional de Investigación y Desarrollo Pesquero (INIDEP). Paseo Victoria Ocampo № 1. Mar del Plata, 7600. \\ Argentina. E-mail: militell@inidep.edu.ar \\ ${ }^{2}$ Consejo Nacional de Investigaciones Científicas y Técnicas (CONICET), República Argentina.
}

\begin{abstract}
SUMMARY: Spawning frequency and batch fecundity were estimated for Brazilian flathead, Percophis brasiliensis, in Argentine coastal waters. Samples of this species were collected during the spawning period in November 1998 and 1999. Spawning frequency, determined using the percentage of females with postovulatory follicles, was about $17 \%$ during November 1998. This percentage indicates that $P$. brasiliensis spawned, on average, once every 6 days during this month. Batch fecundity, estimated from counts of hydrated oocytes, was fitted to a power function of length and a linear function of ovary-free female weight. Batch fecundity ranged from $37,500(47 \mathrm{~cm}$ total length) to 614,300 (68 cm total length) hydrated oocytes. Relative fecundity estimated for the two years sampled ranged from 95 to 672 hydrated oocytes/g of female weight (ovary-free). Annual differences in the size-batch fecundity relationship and in the relative fecundity were observed.
\end{abstract}

Key words: Percophis brasiliensis, reproduction, batch fecundity, spawning frequency, Buenos Aires Province.

\section{INTRODUCTION}

The Brazilian flathead, Percophis brasiliensis (Fam. Percophididae) is a demersal coastal species of the Southwest Atlantic which is distributed from Rio de Janeiro (Brazil) $\left(23^{\circ} \mathrm{S}\right)$ to the north of the Chubut Province (Argentina) $\left(44^{\circ} \mathrm{S}\right)$ (Tomo, 1969; Verazay, 1976; Gosztonyi, 1981; Cousseau and Perrotta, 1998).

The Brazilian flathead constitutes an important resource for the coastal fisheries of Argentina (Fernández Giménez, 1995). The most abundant catch occurs in summer, between $40^{\circ}$ and $43^{\circ} \mathrm{S}$, at depths

\footnotetext{
*Received September 15, 2000. Accepted December 18, 2000
}

between 40 and $75 \mathrm{~m}$. In the last three years fishing activity on this species has increased because the traditional Argentine resource, hake Merluccius hubbsi, has decreased drastically (Aubone et al., in press). In 1997, catches of $P$. brasiliensis were about 11,500 Tn (Estadísticas de Pesca, 1997. Secretaría de Agricultura, Ganadería, Pesca y Alimentación), which exceeded the maximum value recommended for the resource (6,500 Tn; Consejo Federal Pesquero, 1998). Despite the importance of Brazilian flathead as regards abundance and volumes of capture, there are few papers on the biology of this species. Information on age and growth (Tomo, 1969; Perrotta and Fernández Giménez, 1996), morphometric analysis (Verazay, 1976) and distribution, abundance and 
population structure (Fernández Giménez, 1995) were reported. Previous studies on the reproduction of $P$. brasiliensis have addressed the topic of spawning distribution based on macroscopic analysis (Macchi and Acha, 1998). There has been only one previous report including histological analysis of ovaries and describing oocyte development stages, sex ratios and length at first maturity (Militelli and Macchi, in press). Evidence that the Brazilian flathead is a multiple spawner with indeterminate annual fecundity was suggested by these authors. This spawning pattern indicates that it is necessary to determine the batch fecundity and the number of spawnings in the season in order to estimate total egg production (Hunter and Goldberg, 1980).

The objective of the current study is to get a preliminary estimate of spawning frequency and batch fecundity of $P$. brasiliensis in the coastal area of the Buenos Aires Province.

\section{MATERIAL AND METHODS}

Brazilian flathead females were collected during two trawl research cruises carried out in November 1998 and 1999 in waters of Buenos Aires Province $\left(34^{\circ}-42^{\circ} \mathrm{S}\right)$ at depths of less than $50 \mathrm{~m}$. All females were measured to the nearest centimeter (total length, TL) and weighed to the nearest gram (total weight, TW); for histological examination, the ovaries were fixed in $10 \%$ neutral buffer formalin. Females collected during $1998(n=436)$ were randomly selected, including different maturity stages. In 1999 only gravid females with hydrated oocytes were sampled $(n=96)$. In the laboratory, fixed gonads were weighed $(\mathrm{GW})$ and a portion of tissue was removed from the centre of each ovary, dehydrated in methanol, cleared in xilol and embedded in paraffin. Tissues were sectioned at approximately 5$\mu \mathrm{m}$ thick and stained with Harri's hematoxylin followed by eosin counterstain.

Spawning frequency was estimated from 329 mature females collected in November 1998. The daily fraction of spawning females was estimated by the incidence of fish with postovulatory follicles (POF). The structures were classified as day-0, day1 or day-2, following the description given by Goldberg et al. (1984) for Sardinops sagax and by Melo (1994) for Engraulis capensis. According to Hunter and Goldberg (1980), the spawning fraction was determined taking the percentage of day- 1 spawning females.
Batch fecundity (number of oocytes released per spawning) was estimated gravimetrically with the hydrated oocyte method (Hunter and Macewicz, 1985). Samples were examined histologically to determine the presence of POFs and hydrated oocytes. To avoid biases, when estimating batch fecundity, only ovaries with hydrated oocytes and without postovulatory follicles were used. Then this variable was estimated for 96 females (27 in 1998 and 69 in 1999). Three pieces of ovary of approximately $0.1 \mathrm{~g}$ each were sampled from the anterior, middle and posterior section of each gonad and weighed $( \pm 0.1 \mathrm{mg})$, and the number of hydrated oocytes was counted. Batch fecundity was the product of the mean of hydrated oocytes per unit of ovarian weight and total ovarian weight.

Relative fecundity (number of hydrated oocytes per gram of ovary-free body weight) was estimated as the batch fecundity divided by female weight (without ovaries).

The relationships of batch fecundity to total length and total weight (ovary-free) were described using the standard regression. Comparisons between years (1998 and 1999) were based on the overlapping length ranges of females, to which an analysis of covariance was applied (Draper and Smith, 1981). Relative fecundity values obtained in the different years were compared using a test of equality of means.

\section{RESULTS AND DISCUSSION}

During November 1998, the percentage of spawning females with hydrated oocytes was lower than that with postovulatory follicles (Table 1). Day-1 and day-2 postovulatory follicles were present in almost every sample analysed, but only day-1 postovulatory follicles were used to estimate spawning frequency. The percentage of day- 1 spawning females estimated from samples collected in November 1998 was $17.3 \pm 6.6$ (CI 95\%). This percentage indicates that $P$. brasiliensis spawn, on average, once every six days during that month. Since research cruises were only carried out in November, it was not possible to know the extension of the breeding season of Brazilian flathead. However, according to information based on the macroscopical analysis of the ovaries it is possible to consider November-December as the main spawning peak for $P$. brasiliensis in the area (Macchi and Acha, 1998). 
TABLE 1. - Number of reproductively active females of Percophis brasiliensis based on histological staging to determine spawning frequency. $\mathrm{POF}=$ postovulatory follicles.

\begin{tabular}{|c|c|c|c|c|c|}
\hline Day of month & Hydrated oocytes & PFO day-0 & POF day-1 & POF day-2 & Total mature \\
\hline $11 / 25$ & 0 & 0 & 4 & 10 & 21 \\
\hline $11 / 25$ & 2 & 0 & 0 & 2 & 19 \\
\hline $11 / 25$ & 14 & 2 & 5 & 3 & 25 \\
\hline $11 / 25$ & 0 & 0 & 2 & 9 & 16 \\
\hline $11 / 25$ & 3 & 4 & 2 & 3 & 17 \\
\hline $11 / 25$ & 0 & 0 & 2 & 1 & 7 \\
\hline $11 / 26$ & 1 & 0 & 15 & 5 & 23 \\
\hline $11 / 26$ & 0 & 0 & 0 & 2 & 19 \\
\hline $11 / 26$ & 0 & 1 & 2 & 7 & 16 \\
\hline $11 / 27$ & 2 & 1 & 4 & 3 & 14 \\
\hline $11 / 27$ & 0 & 2 & 0 & 0 & 13 \\
\hline $11 / 28$ & 0 & 0 & 0 & 0 & 5 \\
\hline $11 / 28$ & 0 & 5 & 5 & 3 & 13 \\
\hline $11 / 29$ & 0 & 0 & 0 & 2 & 7 \\
\hline $11 / 29$ & 0 & 6 & 4 & 2 & 13 \\
\hline $11 / 30$ & 1 & 0 & 2 & 3 & 11 \\
\hline $11 / 30$ & 0 & 0 & 0 & 1 & 4 \\
\hline $12 / 01$ & 1 & 0 & 3 & 2 & 15 \\
\hline $12 / 01$ & 0 & 0 & 2 & 2 & 16 \\
\hline $12 / 01$ & 4 & 8 & 1 & 3 & 19 \\
\hline $12 / 01$ & 1 & 13 & 10 & 0 & 25 \\
\hline $12 / 02$ & 0 & 1 & 2 & 7 & 11 \\
\hline Total: & 29 & 43 & 65 & 70 & 329 \\
\hline$\%$ (Average) & 7 & 11.3 & 17.3 & 21.8 & \\
\hline $95 \%$ CI & 6.6 & 6.9 & 6.6 & 0.4 & \\
\hline
\end{tabular}
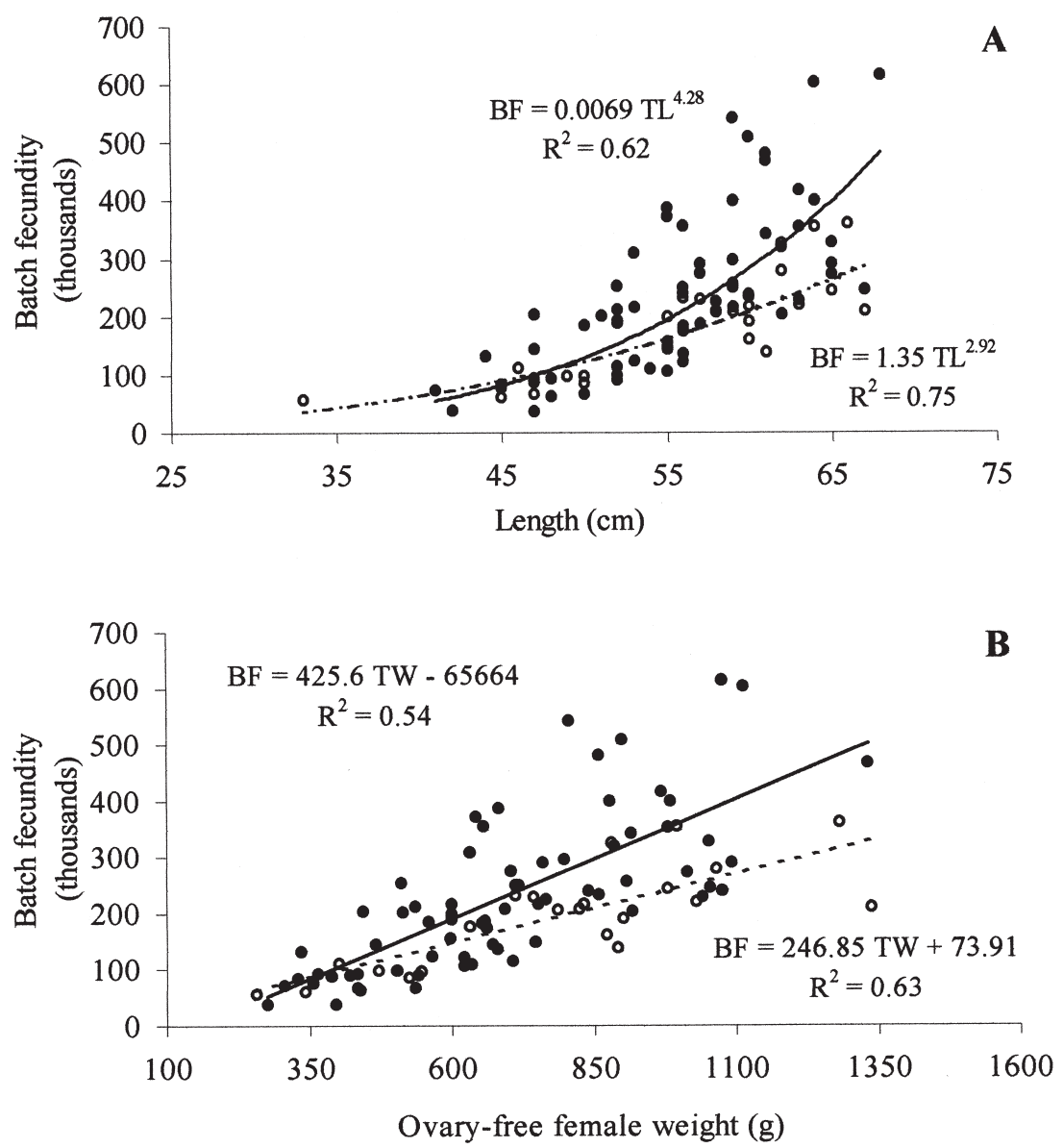

FIG. 1. - Batch fecundity as a function of total length (A) and total weight (without ovary) (B) obtained from November 1998 (white dots and dashed line) and from November 1999 (black dots and fill line). 
Batch fecundity estimated for females caught in November 1998 ranged between 56,200 and 360,700 hydrated oocytes and the mean value was $188,912( \pm 88,143)$ hydrated oocytes. During December 1999 batch fecundity ranged between 37,500 and 614,300 hydrated oocytes with a mean fecundity value of 232,618 $( \pm 135,116)$. Batch fecundity estimated for the two years sampled was fitted to a power function of total length and a linear function of ovary-free body weight (Fig. 1). The analysis of covariance showed significant differences $(\mathrm{P}<0.05)$ in regression coefficients between 1998 and 1999.

Relative fecundity of $P$. brasiliensis ranged from 95 to 672 hydrated oocytes per gram of female (ovary-free). Comparison of this variable between years sampled showed the same pattern as batch fecundity. In 1998 mean relative fecundity $(243 \pm$ 65) was less than that estimated from the samples collected in $1999(319 \pm 129)(\mathrm{P}<0.01)$. Comparison with previous data was not possible because this is the first estimate of batch and relative fecundities reported for $P$. brasiliensis. Relative fecundity values were higher than those obtained for other batch spawners inhabiting coastal waters of Argentina such as Micropogonias furnieri (Macchi et al., 1996) and Cynoscion guatucupa (Macchi, 1998). Future studies about the reproduction of $P$. brasiliensis should include a complete picture of the annual cycle. Considering the duration of the spawning season, the batch fecundity and the spawning frequency, it is possible to get an estimate of the annual egg production for this species.

\section{ACKNOWLEDGEMENTS}

This research was conducted within the INIDEP's Coastal Project. We thank H. Christiansen and T. Carlé for the preparation of histological sections. We also thank N. Rossi for critically reading our manuscript.

\section{REFERENCES}

Aubone, A., M. Pérez, M. Renzi, G. Irusta and S. Bezzi. - 1999. Estado de explotación de la merluza (Merluccius hubbsi) al norte de $41^{\circ} \mathrm{S}$ (Atlántico Sudoccidental) y recomendaciones de manejo para 1998. Rev. Inv. Des. Pesq. INIDEP. Press.

Cousseau, M.B. and R.G. Perrotta. - 1998. Peces Marinos de Argentina: Biología, distribución, pesca. INIDEP, Mar del Plata, Argentina.

Draper, N. and H. Smith. - 1981. Applied regression analysis, second edition. J.Wiley \& Sons, New York.

Fernandez Gimenez, A.V. - 1995. Estimación de la biomasa y análisis de la estructura poblacional del pez palo (Percophis brasiliensis, Quoy et Gaimard 1824), entre los $37^{\circ}$ y $42^{\circ} \mathrm{LS}$ en el invierno de 1993. Thesis, Universidad Nacional de Mar del Plata.

Goldberg, S.R., V.H. Alarcón and J. Alheith. - 1984. Postovulatory follicle histology of the Pacific sardine, Sardinops sagax, from Peru. Fish. Bull., U.S., 82(2): 443-445.

Gosztonyi, A.E. - 1981. Resultados de las investigaciones ictiológicas de la campaña I del B/I "Shinkai Maru" en el mar argentino (10.04-09.05 1978). In: V. Angelescu (ed.). Campañas de investigación pesquera realizadas en el mar argentino por los B/I "Shinkai Maru” y "Walther Herwing" y el B/P "Marburg”, años 1978 y 1979. Resultados de la parte argentina, pp. 254-266. Contribución INIDEP.

Hunter, J.R. and S.R. Goldberg. - 1980. Spawning incidence and batch fecundity in northern anchovy, Engraulis mordax. Fish. Bull., U.S., 77 (3): 641-652.

Hunter, J.R. and B.J. Macewicz. - 1985. Rates of atresia in the ovary of captive and wild northern anchovy, Engraulis mordax. Fish. Bull., U.S., 83(2): 119-136.

Macchi, G.J., E.M. Acha and C.A. Lasta. - 1996. Desove y fecundidad de la corvina rubia Micropogonias furnieri Desmarest, 1823 del estuario del Río de la Plata, Argentina. Bol. Inst. Esp. Oceanogr., 12(2): 99-113.

Macchi, G.J. - 1998. Preliminary estimate of spawning frequency and batch fecundity of striped weakfish, Cynoscion striatus, in coastal waters off Buenos Aires province. Fish. Bull., U.S., 96(2): 375-381.

Macchi, G.J. and E.M. Acha - 1998. Aspectos reproductivos de las principales especies de peces en la Zona Común de Pesca Argentino-Uruguaya y en El Rincón. Noviembre, 1994.In: C.A. Lasta (ed.). Resultados de una campaña de evaluación de recursos demersales costeros de la provincia de Buenos Aires y del Litoral Uruguayo. Noviembre, 1994. Inf. Tec. INIDEP, 21: 67-89.

Melo, Y.C. - 1994. Spawning frequency of the anchovy Engraulis capensis. S. Afr. J. Mar. Sci., 14: 321-331.

Militelli, M.I. and G.J. Macchi. - 2000. Reproducción del pez palo (Percophis brasiliensis) en aguas costeras de la provincia de Buenos Aires. Rev. Inv. Des. Pesq. INIDEP. Press.

Perrotta, R.G. and A. Fernández Giménez. - 1996. Estudio preliminar sobre la edad y el crecimiento del pez palo (Percophis brasiliensis Quoy et Gaimard 1824). Inf. Tec. INIDEP, 10: 25-36.

Tomo, A. - 1969. Edad, crecimiento y algún dato que hacen al conocimiento de la biología del pez palo Percophis brasiliensis Quoy et Gaimard de la región de Mar del Plata. Thesis, Universidad Nacional de Buenos Aires.

Verazay, G.A. - 1976. Contribución al estudio del pez palo, Percophis brasiliensis Quoy et Gaimard (Pisces, Percophididae). Thesis, Universidad Nacional de Buenos Aires.

Scient ed.: E. Macpherson 